\title{
The Use of 3-Bezylidene Phthalide as Synthon in Synthesis of Heterocyclic Compounds
}

\author{
Shaymaa K. Younis \\ Department of Chemistry \\ College of Science \\ University of Mosul
}

Email:khazaalyounis@yahoo.com

(Received 20/9/2010; Accepted 25/4/2011)

\begin{abstract}
2-( $\alpha$-Phenylacetyl) benzohydrazide (1) was prepared through the reaction of (Z)-3benzylidene phthalide and hydrazine hydrate. Treatment of compound (1) with substituted benzoyl chloride yielded N'-aroyl-2-( $\alpha$-phenyl acetyl) benzohydrazide (2a-e) which upon reaction with ammonium acetate provided the corresponding 2-phenyl-1-(2-(5-aryl-1,2,4triazole-3-yl)phenyl)ethanones (3a-e). While the reaction of compound (1) with substituted benzaldehyde gave the hydrazones represented by N'-arylidene-2-( $\alpha$-phenylacetyl) benzohydrazide derivatives (4a-f). Intramolecule cyclization of the latter compounds by means of acetic anhydride yielded 2-( $\alpha$-phenylacetyl)phenyl-4-acetyl-4,5-dihydro-5-aryl-1,3,4oxadiazoles (5a-f).

Compounds 2-( $\alpha$-phenylacetyl)-N-(3,6-diphenyl-5-aryl-5,6-dihydro-1,2,4-triazine-4yl) benzamide (6a-f) were also obtained from the direct Diel-Alder reaction between dibenzylidine hydrazine as diene and compounds (4a-f) as dienophile enhanced by microwave irradiation.

The assigned structure of the prepared compounds were corroborated by available physical and spectral methods.
\end{abstract}

Keywords: (Z)-3-benzylidene phthalide, 2-( $\alpha$-phenylacetyl) benzohydrazide.

\section{الستخلم 3 -بنزاليلينينفثلاليد كماة أوليةفي تحضيرمركبك حلفية غيرمتجلنة}

\section{الملذص}

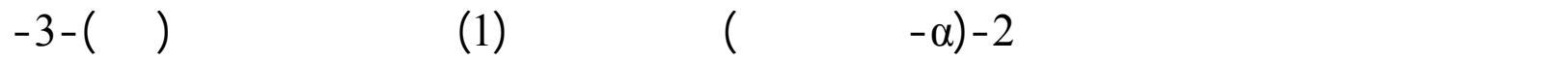

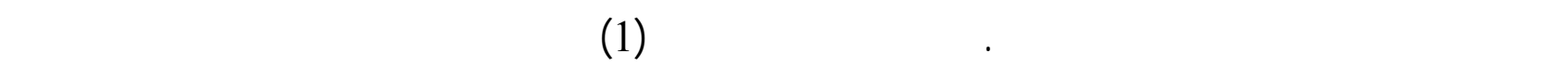

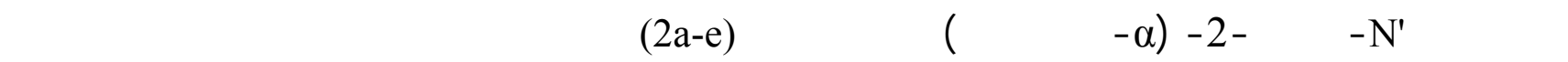




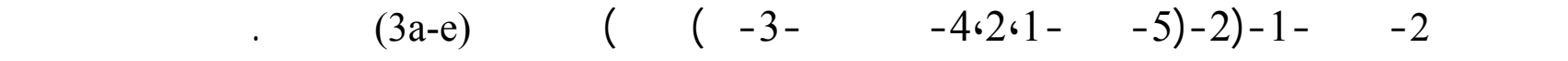

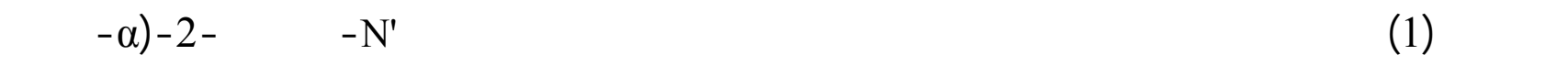

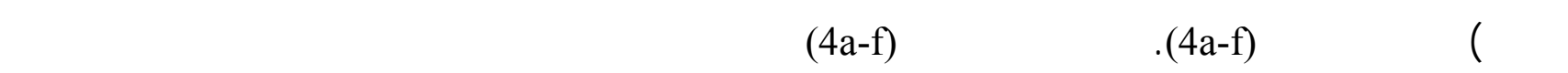

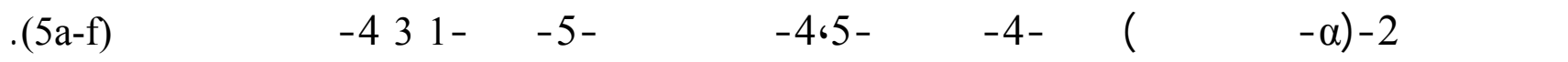

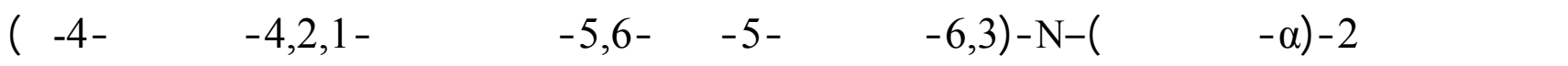

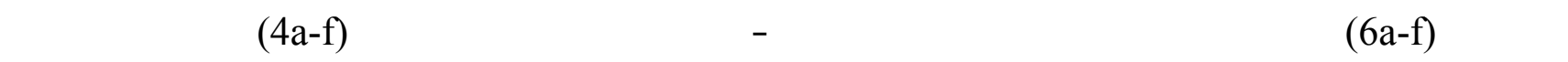

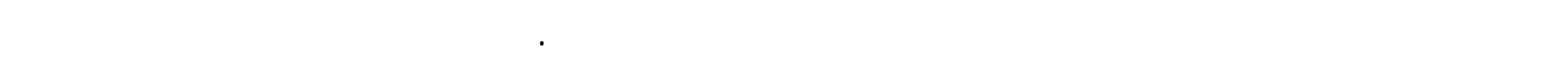
بلستخدلم الطرايق الفيزياوية والطيفية المتوفرة.

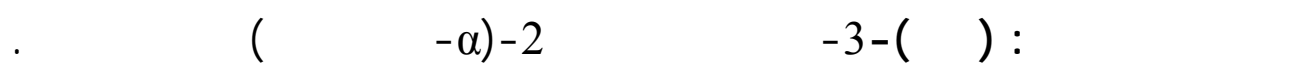

\section{INTRODUCTION}

Among many class of small molecule libraries, 3-benzylidene(alkylidene) phthalides are very attractive template for combinatorial synthesis, due to the large number of substitution pattrens (Dalloul, 2010; Viña et al., 2009; del Olmo et al., 2006; Rios and Delgado, 1999; Hrnčiar et al., 1994; Humber, 1974; Rosenthal and Yalpani, 1965; Litvan and Stoll, 1958) and also it have a great deals of attention because of it s wide applications in idusterial (Shibata and Gaesser, 1991; Scholl et al., 1989; Conner, 1982) and biological fields (Kurume et al., 2008; Kanazawa and Terada, 2007; Kundu et al., 1998; Ganji et al., 1993; Ibrahim, 1991).

In this presentation 3-benzylidene phthalide was used as active synthon to obtain different heterocyclic compounds represented by 1,2,4-triazoles that have many biological, pharmaceutical and agricultural applications (Khanage et al., 2010; Singh, 2009; Taha and AlBadry, 2006; Hsu et al., 2005; Sasaki et al.,1984; Katratizky and Rees, 1984), 1,3,4oxadiazoles which present in compounds have higher biological, pharmaceutical and agricultural activities (Swamy et al., 2010; mulwad and Chashar,2006; Khare et al., 2005; Mishra and Singh, 2000; Katratizky and Rees, 1984), and 1,2,4-triazines that have also reported to exhibit various pharmaceutical properties and wide applications in agricultural and idusterial fields (Dalloul and Al-Shorafa, 2009; Kamble and Sudha, 2006; Nasr, 2005).

Prompted by these observations and starting from (Z)-3-benzylidene phthalide, the series of new 1,2,4-trazoles (3a-e), and 1,3,4-oxadiazoles (5a-f) were commonly performed under usual mild and thermal methods, while a simple and efficient one-pot procedure was followed for generation of 1,2,4-triazines (6a-f) with microwave assistance. The use of microwave energy to activated organic reactions has taken a new dimention in the last few years, due to its supreme properties represented by an excellent approach for the safe, rapid, enviromentally safe, inexpensive and yield enhancement (Deka et al., 2001; Chérouvrier and Bazureau, 2001; Xiuying et al., 2003; Yan et al., 2007). 


\section{EXPERIMENTAL}

Melting points (M.P.) were measured on Electrothermal, Gallenkamp melting point apparatus and are uncorrected. Proton-Nuclear Magnetic Resonance ( $\left.{ }^{1} \mathrm{H}-\mathrm{NMR}\right)$ spectra were recorded using, spectrophotometer $(\mathrm{H} 300 \mathrm{MHz})$; with TMS as internal standard, and DMSO- $\mathrm{d}_{6}$ as a solvent; Jorden, University of Al-Bayt. [(s) singlet; (d) doublet; (m) multiplet]. Infrared (FT-IR) spectra were recorded as (KBr) disc using a Bruker, FT-IR, spectrophotometer tensor 27 and FT-IR-600, Biotech Engineering Mangment CO. LTD. (UK ). Ultraviolet (UV) spectra were performed on Shimadzu UV-Visible spectrophotometer UV-1650 PC using methanol as a solvent. The microwave oven is a domestic microwave oven (LG, MS-192W), (360watt) irradiation was used. The starting material (Z)-3-benzylidene phthalide was manufactured by Fluka Com. (Germany). Finally, thin layer chromatography (T.L.C) were carried out on silica gel $(120 \mathrm{mesh})$ coated plates $(2 \times 10) \mathrm{cm}$, one hour activated at $\left(110-120^{\circ} \mathrm{C}\right)$ before use .

Synthesis of 2-( $\alpha$-phenylacetyl) benzohydrazide (1): (Del Olmo et al., 2006, 2010; Shafiee et al., 1995)

To a solution of (Z)-3-benzylidene phthalide $(2.22 \mathrm{gm}, 1 \mathrm{mmole})$ in ethanol $(25 \mathrm{ml})$, hydrazine hydrate $(80 \%)$ ( $2.5 \mathrm{gm}, 0.05$ mole) was added dropwise. The resulting mixture was vigorously stirred for $(5 \mathrm{hrs}$.), then poured on $(100 \mathrm{ml})$ ice-water. The white precipitate was filtered off and washed thoroughly with water and crystallized from ethanol to give (1.7 gm, $73 \%)$ of compound (1); m.p $\left(195-196^{\circ} \mathrm{C}\right)$; The purity of the obtained product was controlled by TLC technique using solvent system (ethyl acetate:dichloromethane) in (2:8) ratio, $\mathrm{R}_{\mathrm{f}}$ value (0.330); $\quad \mathrm{H}^{1}-\mathrm{NMR} \quad\left(\mathrm{DMSO}_{-} \mathrm{d}_{6}\right) \quad \delta / \mathrm{ppm}: \quad 3.4\left(1 \mathrm{H}, \mathrm{NH}_{2}\right), \quad 4.3\left(2 \mathrm{H}, \mathrm{CH}_{2}\right), \quad 7.1-8.2(\mathrm{H}-\mathrm{Ar})$ and 12,4(1H,NH); FT-IR (KBr) v/cm ${ }^{-1}: 3340\left(\mathrm{NH}_{2}\right), 3161(\mathrm{NH}), 1692(\mathrm{C}=\mathrm{O}$ ketone $), 1660(\mathrm{C}=\mathrm{O}$ amide), and $1076(\mathrm{~N}-\mathrm{N})$; UV (methanol, $\left.\lambda_{\max }\right): 242 \mathrm{~nm}$.

Synthesis of $N^{\prime}$-aroyl-2-( $\alpha$-phenylacetyl) benzohydrazide (2a-e): (Patel et al., 2010; Sobkowski, 2008; Trotsko et al., 2007)

Substituted benzoyl chloride (5 mmole) was added to a stirred solution of compound (1) $(1.2 \mathrm{gm}, 5 \mathrm{mmole})$ in pyridine $(10 \mathrm{ml})$ and catalytic amount of triethylamine $(1 \mathrm{ml})$. The mixture was stirred for (20) minutes at room temperature, then refluxed for $(2 \mathrm{hrs}$.). The reaction mixture was brought to room temperature and left overnight. The precipitated solid was filtered off, washed with ether $(3 \times 15 \mathrm{ml})$, and dried then recrystallized from ethanol to yield compounds (2a-e). The completion of the reaction was monitored by thin layer chromatography (TLC) and the physical and spectral data were shown in Table (1). 
Table 1: Physical properties and spectral data for compounds (2a-e).

\begin{tabular}{|c|c|c|c|c|c|c|c|c|c|c|c|}
\hline \multirow{2}{*}{$\begin{array}{c}\text { Comp. } \\
\text { No. }\end{array}$} & \multirow[b]{2}{*}{$\mathbf{x}$} & \multirow{2}{*}{$\begin{array}{l}\text { M.P. } \\
\left({ }^{\circ} \mathbf{C}\right)\end{array}$} & \multirow{2}{*}{$\begin{array}{c}\text { Yield } \\
(\%)\end{array}$} & \multirow{2}{*}{$\begin{array}{c}\mathbf{R}_{\mathrm{f}} \\
\text { Value }\end{array}$} & \multirow{2}{*}{$\begin{array}{c}\mathrm{UV} \\
(\mathrm{MeOH}) \\
\lambda_{\max } \\
(\mathbf{n m})\end{array}$} & \multicolumn{6}{|c|}{ I.R $(\mathrm{KBr}) v\left(\mathrm{~cm}^{-1}\right)$} \\
\hline & & & & & & $\mathrm{N}-\mathrm{H}$ & $\begin{array}{c}\mathrm{C}=\mathbf{O} \\
\text { (ketone) }\end{array}$ & $\begin{array}{c}\mathbf{C}=\mathbf{O} \\
\text { (amide) }\end{array}$ & $\begin{array}{l}C=C \\
\text { (Ar) }\end{array}$ & $\mathrm{N}-\mathrm{N}$ & others \\
\hline $2 a$ & $\mathrm{H}$ & $238-240$ & 95 & 0.26 & 226 & 3203 & 1709 & 1664 & 1601,1475 & 1076 & - \\
\hline $2 b$ & $\mathrm{p}-\mathrm{Cl}$ & $174-177$ & 94 & 0.23 & 236 & 3222 & 1736 & 1682 & 1600,1493 & 1092 & - \\
\hline $2 \mathrm{c}$ & 2,4-di Cl & $243-244$ & 91 & 0.21 & 232 & 3184 & 1720 & 1687 & 1609,1475 & 1078 & - \\
\hline $2 d$ & $\mathrm{p}-\mathrm{NO}_{2}$ & $152-154$ & 72 & 0.22 & 232 & 3159 & 1712 & 1658 & 1604,1477 & 1076 & $\begin{array}{c}\mathrm{NO}_{2} \\
\text { asym } 1523 \\
\text { sym } 1358\end{array}$ \\
\hline $2 \mathrm{e}$ & 3,5-di $\mathrm{NO}_{2}$ & $240-242$ & 74 & 0.25 & 232 & 3232 & 1720 & 1658 & 1608,1475 & 1072 & $\begin{array}{c}\mathrm{NO}_{2} \\
\text { asym1535; } \\
\text { sym } 1331\end{array}$ \\
\hline
\end{tabular}

\section{Synthesis of 2-phenyl-1-(2-(5-aryl-1,2,4-triazole-3-yl)phenyl)ethanones (3a-e): (Konda,} 2010, Abd El-Fattah et al., 2010; Nasr, 2005)

A mixture of compounds $(2 \mathrm{a}-\mathrm{e})(0.3 \mathrm{mmole})$ and ammonium acetate $(0.6 \mathrm{mmole})$ in methanol $(25 \mathrm{ml})$ was heated under reflux for $(5 \mathrm{hrs}$.), then left to cool to room temperature. The reaction mixture was poured into cold water for complete precipitation, then the solid obtained was filtered off, washed with ether $(2 \times 5 \mathrm{ml})$. The crude product was crystallized from methanol to give compounds (3a-e). The completion of the reaction was monitored by thin layer chromatography (TLC) (ethyl acetate: dichloro methane, 2:8 ratio) and the physical and spectral data were shown in Table (2).

Table 2: Physical properties and spectral data for compounds (3a-e).

\begin{tabular}{|c|c|c|c|c|c|c|c|c|c|c|c|}
\hline \multirow{2}{*}{$\begin{array}{c}\text { Comp. } \\
\text { No. }\end{array}$} & \multirow[b]{2}{*}{$\mathbf{X}$} & \multirow{2}{*}{$\begin{array}{l}\text { M.P. } \\
\left({ }^{\circ} \mathbf{C}\right)\end{array}$} & \multirow{2}{*}{$\begin{array}{c}\text { Yield } \\
(\%)\end{array}$} & \multirow{2}{*}{$\begin{array}{c}\mathbf{R}_{\mathbf{f}} \\
\text { Value }\end{array}$} & \multirow{2}{*}{$\begin{array}{c}\mathbf{U V} \\
(\mathrm{MeOH}) \\
\lambda_{\max } \\
(\mathrm{nm}) \\
\end{array}$} & \multicolumn{6}{|c|}{ I.R (KBr)v $\left(\mathrm{cm}^{-1}\right)$} \\
\hline & & & & & & N-H & $\mathbf{C}=\mathbf{O}$ & $\begin{array}{l}C=C \\
\text { (Ar) }\end{array}$ & $\begin{array}{c}\mathrm{C}=\mathrm{N} \\
\text { (cyclic) }\end{array}$ & $\mathbf{N}-\mathbf{N}$ & others \\
\hline $3 a$ & $\mathrm{H}$ & $215-218$ & 82 & 0.50 & 268 & 3180 & 1668 & 1603,1481 & 1631 & 1078 & - \\
\hline $3 b$ & $\mathrm{p}-\mathrm{Cl}$ & 192-194 & 92 & 0.45 & 268 & 3200 & 1682 & 1604,1479 & 1591 & 1092 & - \\
\hline $3 \mathrm{c}$ & 2,4-di Cl & $221-223$ & 75 & 0.35 & 264 & 3159 & 1665 & 1616,1475 & 1575 & 1072 & - \\
\hline $3 d$ & $\mathrm{p}-\mathrm{NO}_{2}$ & 190-192 & 82 & 0.37 & 256 & 3244 & 1658 & 1608,1493 & 1554 & 1076 & $\begin{array}{c}\mathrm{NO}_{2} \\
\text { asym1554 } \\
\text { sym } 1338\end{array}$ \\
\hline $3 e$ & 3,5 -di $\mathrm{NO}_{2}$ & $218-220$ & 65 & 0.31 & 276 & 3140 & 1662 & 1611,1479 & 1572 & 1072 & $\begin{array}{c}\mathrm{NO}_{2} \\
\text { asym } 1533 ; \\
\text { sym } 1365\end{array}$ \\
\hline
\end{tabular}




\section{Synthesis of N'-arylidene-2-( $\alpha$-phenylacetyl)benzohydrazide (4a-f): (Kotb, 2009)}

A mixture of compound (1) (2.36 gm, 10 mmole) and equimolar amount of the substituted benzaldehyde in absolute ethanol $(20 \mathrm{ml})$ was refluxed for $(8 \mathrm{hrs}$.). The solution was cooled, the precipitate formed was filtered off and recrystallized from methanol to give compounds (4a-f). The completion of reaction was followed by TLC (ethyl acetate: dichloro methane, 2:8 ratio). The physical and spectral data were listed in Table (3).

Table 3: Physical properties and spectral data for compounds (4a-f).

\begin{tabular}{|c|c|c|c|c|c|c|c|c|c|c|c|c|}
\hline \multirow{2}{*}{$\begin{array}{c}\text { Comp. } \\
\text { No. }\end{array}$} & \multirow[b]{2}{*}{$\mathbf{X}$} & \multirow{2}{*}{$\begin{array}{l}\text { M.P. } \\
\left({ }^{\circ} \mathbf{C}\right)\end{array}$} & \multirow{2}{*}{$\begin{array}{l}\text { Yield } \\
(\%)\end{array}$} & \multirow{2}{*}{$\begin{array}{c}\mathbf{R}_{\mathrm{f}} \\
\text { Value }\end{array}$} & \multirow{2}{*}{$\begin{array}{c}\text { UV } \\
(\mathrm{MeOH}) \\
\lambda_{\max } \\
(\mathbf{n m})\end{array}$} & \multicolumn{7}{|c|}{$\operatorname{I.R}(\mathrm{KBr}) v\left(\mathrm{~cm}^{-1}\right)$} \\
\hline & & & & & & N-H & $\begin{array}{l}\mathrm{C}=\mathbf{O} \\
\text { (ketone) }\end{array}$ & $\begin{array}{c}\mathrm{C}=\mathbf{O} \\
\text { (amide) }\end{array}$ & $\begin{array}{l}C=C \\
\text { (Ar) }\end{array}$ & $\mathbf{C}=\mathbf{N}$ & $\mathbf{N}-\mathbf{N}=\mathbf{C}$ & others \\
\hline $4 a$ & $\mathrm{H}$ & $172-174$ & 73 & 0.53 & 284 & 3180 & 1728 & 1661 & 1601,1493 & 1560 & 1542 & - \\
\hline $4 b$ & $\mathrm{p}-\mathrm{OMe}$ & $155-156$ & 69 & 0.47 & 328 & 3161 & 1704 & 1658 & 1600,1493 & 1563 & 1547 & $\begin{array}{c}\text { acyclic } \\
\text { C-O-C, } \\
1181\end{array}$ \\
\hline $4 c$ & $\begin{array}{l}2,4- \\
\text { diOMe }\end{array}$ & $176-177$ & 61 & 0.39 & 352 & 3165 & 1720 & 1658 & 1603,1493 & 1580 & 1549 & $\begin{array}{c}\text { acyclic } \\
\text { C-O-C, } \\
1181\end{array}$ \\
\hline $4 d$ & $\begin{array}{c}3,4- \\
\mathrm{diOMe}\end{array}$ & $177-179$ & 65 & 0.42 & 304 & 3223 & 1711 & 1655 & 1602,1508 & 1597 & 1579 & $\begin{array}{c}\text { acyclic } \\
\text { C-O-C, } \\
1188\end{array}$ \\
\hline $4 \mathrm{e}$ & $\mathrm{o}-\mathrm{Cl}$ & $138-139$ & 84 & 0.38 & 344 & 3239 & 1727 & 1655 & 1608,1491 & 1587 & 1564 & - \\
\hline $4 \mathrm{f}$ & $\mathrm{p}-\mathrm{Cl}$ & 174-175 & 90 & 0.45 & 308 & 3211 & 1720 & 1657 & 1608,1491 & 1593 & 1558 & - \\
\hline
\end{tabular}

Synthesis of 2-( $\alpha$-phenyl acetyl)phenyl-4-acetyl-4,5-dihydro-5-aryl-1,3,4-oxadiazole (5a-f): ( Kotb, 2009; Islam and Mohsin, 2007; Shaban et al., 1991 )

A mixture of compounds (4a-f) $(0.5$ mmole $)$ and acetic anhydride $(7 \mathrm{ml})$ were refluxed for ( 3 hrs.). The excess of acetic anhydride and acetic acid were removed in vacuo and the solid residue was filtered off, washed with water, dried and recrystallized from ethanol to give the compounds (5a-f). The completion of reaction was followed by TLC (ethyl acetate: dichloro methane, 2:8 ratio). The physical and spectral data were given in Table (4). 
Table 4: Physical properties and spectral data for compounds (5a-f)

\begin{tabular}{|c|c|c|c|c|c|c|c|c|c|c|c|}
\hline \multirow{2}{*}{$\begin{array}{c}\text { Comp. } \\
\text { No. }\end{array}$} & \multirow{2}{*}{$\mathbf{X}$} & \multirow{2}{*}{$\begin{array}{l}\text { M.P. } \\
\left({ }^{\circ} \mathbf{C}\right)\end{array}$} & \multirow{2}{*}{$\begin{array}{l}\text { Yield } \\
(\%)\end{array}$} & \multirow{2}{*}{$\begin{array}{c}\mathbf{R}_{\mathrm{f}} \\
\text { Value }\end{array}$} & \multirow{2}{*}{$\begin{array}{c}\text { UV } \\
(\mathrm{MeOH}) \\
\lambda_{\max } \\
(\mathbf{n m})\end{array}$} & \multicolumn{6}{|c|}{$\operatorname{I.R}(\mathrm{KBr}) v\left(\mathrm{~cm}^{-1}\right)$} \\
\hline & & & & & & $\begin{array}{c}\mathrm{C}=\mathbf{O} \\
\text { (ketone) }\end{array}$ & $\begin{array}{c}\mathrm{C}=\mathbf{O} \\
\text { (amide) }\end{array}$ & $\begin{array}{l}\mathrm{C}=\mathrm{C} \\
\text { (Ar) }\end{array}$ & $\mathbf{C}=\mathbf{N}$ & $\begin{array}{l}\mathrm{C}-\mathrm{O}-\mathrm{C} \\
\text { (cyclic) }\end{array}$ & others \\
\hline $5 \mathrm{a}$ & $\mathrm{H}$ & $96-97$ & 69 & 0.45 & 232 & 1759 & 1674 & 1608,1495 & 1597 & 1190 & - \\
\hline $5 b$ & $\mathrm{p}-\mathrm{OMe}$ & $88-89$ & 95 & 0.41 & 234 & 1759 & 1672 & 1610,1495 & 1597 & 1190 & $\begin{array}{c}\text { acyclic } \\
\text { C-O-C, } 1126\end{array}$ \\
\hline $5 \mathrm{c}$ & 2,4-diOMe & $92-94$ & 85 & 0.36 & 236 & 1755 & 1668 & 1600,1493 & 1597 & 1190 & $\begin{array}{c}\text { acyclic } \\
\text { C-O-C,1124 }\end{array}$ \\
\hline $5 d$ & 3,4-diOMe & $157-160$ & 90 & 0.38 & 232 & 1759 & 1660 & 1600,1493 & 1597 & 1182 & $\begin{array}{c}\text { acyclic } \\
\text { C-O-C, } 1153\end{array}$ \\
\hline $5 e$ & $\mathrm{o}-\mathrm{Cl}$ & $94-95$ & 84 & 0.43 & 236 & 1751 & 1672 & 1601,1495 & 1558 & 1163 & - \\
\hline $5 \mathrm{f}$ & $\mathrm{p}-\mathrm{Cl}$ & $170-171$ & 89 & 0.40 & 250 & 1709 & 1650 & 1616,1491 & 1591 & 1180 & - \\
\hline
\end{tabular}

\section{Synthesis of 2-( $\alpha$-phenylacetyl)-N-(3,6-diphenyl-5-aryl-5,6-dihydro-1,2,4-triazine-4-yl)}

\section{benzamide (6a-f): (Lenardao et al., 2007)}

Equimolar of compounds (4a-f) and dibenzylidine hydrazine(which was prepared using a previously reported method, Sharma et al, 2008) were irradiated in a microwave oven for (6 min.) at (360 watt). After cooling, cold water was added to the reaction mixture, the solid obtained was then filtered off and recrystallized from ethanol. The completion of reaction was followed by TLC (ethyl acetate: dichloro methane, 2:8 ratio). The physical and spectral data were listed in Tables (5).

Table 5: Physical properties and spectral data for compounds (6a-f)

\begin{tabular}{|c|c|c|c|c|c|c|c|c|c|c|c|c|c|}
\hline \multirow{2}{*}{$\begin{array}{c}\text { Comp. } \\
\text { No. }\end{array}$} & \multirow[b]{2}{*}{$\mathbf{X}$} & \multirow{2}{*}{$\begin{array}{l}\text { M.P. } \\
\left({ }^{\circ} \mathrm{C}\right)\end{array}$} & \multirow{2}{*}{$\begin{array}{c}\text { Yield } \\
(\%)\end{array}$} & \multirow{2}{*}{$\begin{array}{c}\mathbf{R}_{\mathbf{f}} \\
\text { Value }\end{array}$} & \multirow{2}{*}{$\begin{array}{c}\text { UV } \\
(\mathrm{MeOH}) \\
\lambda_{\max } \\
(\mathbf{n m})\end{array}$} & \multicolumn{8}{|c|}{$\operatorname{I.R}(\mathrm{KBr}) v\left(\mathrm{~cm}^{-1}\right)$} \\
\hline & & & & & & N-H & $\begin{array}{c}\mathrm{C}=\mathbf{O} \\
\text { (ketone) }\end{array}$ & $\begin{array}{c}\mathrm{C}=\mathbf{O} \\
\text { (amide) }\end{array}$ & $\begin{array}{l}C=C \\
\text { (Ar) }\end{array}$ & $\mathbf{N}=\mathbf{N}$ & C-N & $\mathbf{N}-\mathbf{N}$ & others \\
\hline $6 a$ & $\mathrm{H}$ & $120-121$ & 85 & 0.49 & 298 & 3356 & 1733 & 1656 & 1625,1493 & 1577 & 1348 & 1075 & - \\
\hline $6 \mathrm{~b}$ & $\mathrm{p}-\mathrm{OMe}$ & $110-112$ & 74 & 0.36 & 300 & 3328 & 1750 & 1656 & 1625,1492 & 1556 & 1378 & 1074 & $\begin{array}{c}\text { acyclic } \\
\text { C-O-C } \\
1151\end{array}$ \\
\hline $6 c$ & $\begin{array}{c}2,4- \\
\text { diOMe }\end{array}$ & $130-132$ & 69 & 0.31 & 298 & 3340 & 1713 & 1656 & 1622,1493 & 1589 & 1348 & 1076 & $\begin{array}{c}\text { acyclic } \\
\text { C-O-C } \\
1152\end{array}$ \\
\hline $6 \mathrm{~d}$ & $\begin{array}{c}3,4- \\
\text { diOMe }\end{array}$ & $119-120$ & 69 & 0.33 & 300 & 3289 & 1718 & 1655 & 1622,1492 & 1574 & 1346 & 1074 & $\begin{array}{c}\text { acyclic } \\
\text { C-O-C } \\
1152\end{array}$ \\
\hline $6 e$ & $\mathrm{o}-\mathrm{Cl}$ & $116-118$ & 98 & 0.45 & 304 & 3290 & 1714 & 1657 & 1618,1491 & 1591 & 1354 & 1084 & - \\
\hline $6 f$ & $\mathrm{p}-\mathrm{Cl}$ & $120-122$ & 83 & 0.42 & 298 & 3300 & 1739 & 1655 & 1622,1491 & 1593 & 1354 & 1076 & - \\
\hline
\end{tabular}




\section{RESULTS AND DISCUSSION}

The synthetic pathway leading to the title compounds is given in scheme (7). Usually, the key intermediate 2-( $\alpha$-phenyl acetyl) benzohydrazide (1) was achieved by stirring the (Z)-3benzylidene phthalide and hydrazine hydrate $(80 \%)$ in ethanol according to the previously described procedure (equation 1). Scheme (1) summarized the mechanism probably proceeded for this reaction, (Chiriac et al., 2007; Youssef, 2006) .<smiles>O=C1O/C(=C\c2ccccc2)c2ccccc21</smiles>

3-Benzylidene phthalide<smiles>NCCOc1ccc(C(=O)NN)c(C(=O)Cc2ccccc2)c1</smiles>

(1)

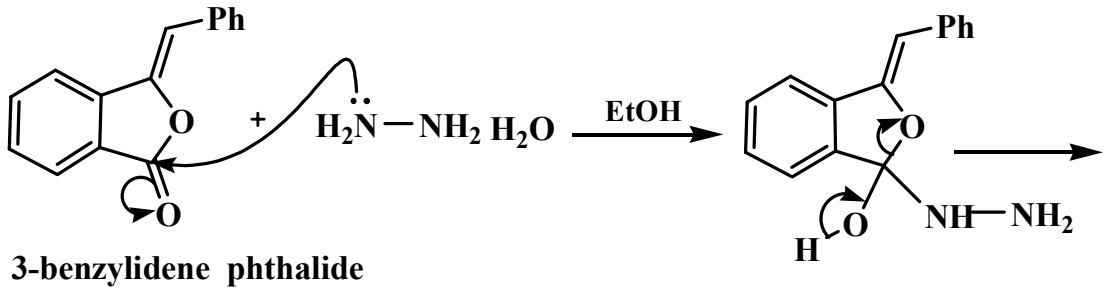

Scheme (1)<smiles>NNC(=O)c1ccccc1/C(=C\c1ccccc1)C(=O)O</smiles><smiles>C=COC(=O)c1ccccc1C(=O)NN</smiles>

(1)

The structure of compound (1) was established on the bases of spectral data. Thus, it's IR spectrum display appearance of absorption bands at $\left(3340 \mathrm{~cm}^{-1}\right),\left(3161 \mathrm{~cm}^{-1}\right),\left(1692 \mathrm{~cm}^{-1}\right)$, $\left(1658 \mathrm{~cm}^{-1}\right)$ and $\left(1076 \mathrm{~cm}^{-1}\right)$ due to $\mathrm{NH}_{2}, \mathrm{NH}, \mathrm{C}=\mathrm{O}$ (ketone) and $\mathrm{C}=\mathrm{O}$ (amide) and $\mathrm{N}-\mathrm{N}$ functional groups respectively. While, the UV spectrum showed absorbtion band at $\lambda_{\max }(242$ $\mathrm{nm}$ ) due to the $\mathrm{n} \rightarrow \pi^{*}$ transition (Finar,1977; Parkh, 1974). Further structure proof of compound (1) has came from ${ }^{1} \mathrm{H}-\mathrm{NMR}$ spectrum which showed significant peaks at $\delta(\mathrm{ppm})$ : $3.4\left(\mathrm{~s}, 2 \mathrm{H}, \mathrm{NH}_{2}\right), 4.3\left(\mathrm{~s}, 2 \mathrm{H}, \mathrm{CH}_{2}\right), 7.1-8.2(\mathrm{~m}, \mathrm{H}$-aromatic) and $12.6(\mathrm{~s}, 1 \mathrm{H}, \mathrm{NH})$. 
Treatment of compounds (1) with substituted benzoyl chloride in pyridine and catalytic amounts of triethylamine afforded the N'-aroyl-2-( $\alpha$-phenyl acetyl) benzohydrazide derivatives (2a-e) in good yields as shown in equation (2), (Ferwanah and Awadallah, 2005; Yildirim et al., 2005; Demirbas et al., 2005).<smiles>NNC(=O)c1ccccc1C(=O)Cc1ccccc1</smiles>

(1)<smiles>[X]c1ccc(C(=O)NNC(=O)c2ccc(C(C)C)cc2C(=O)Cc2ccccc2)cc1</smiles>

$$
\left[\mathrm{X}=\mathrm{H} ; \mathrm{p}-\mathrm{Cl} ; 2,4-\mathrm{di} \mathrm{Cl} ;{\mathrm{p}-\mathrm{NO}_{2} ; 3,5-\mathrm{di} \mathrm{NO}}_{2}\right]
$$

The structure of these compounds was confirmed by means of IR and UV spectra, Table (1). The IR spectra show the characteristic $\mathrm{N}-\mathrm{H}, \mathrm{C}=\mathrm{O}$ (ketone), $\mathrm{C}=\mathrm{O}$ (amide), $\mathrm{C}=\mathrm{C}$ (aromatic) and N-N absorption bands appeared at $\left(3159-3222 \mathrm{~cm}^{-1}\right),\left(1709-1736 \mathrm{~cm}^{-1}\right),\left(1658-1687 \mathrm{~cm}^{-1}\right)$, $\left(1600-1609 ; 1475-1493 \mathrm{~cm}^{-1}\right)$ and $\left(1072-1092 \mathrm{~cm}^{-1}\right)$ respectively and the band at $\left(3379 \mathrm{~cm}^{-1}\right)$ which assigned to $\mathrm{NH}_{2}$ functional group in compound(1) was disappeared. The absence of this band indicates the convertion of the $\mathrm{NH}_{2}$ group in to $\mathrm{NH}$ amido group. Also, the UV spectra of these compounds showed decreases in the absorption wavelength at $\lambda_{\max }(220-236 \mathrm{~nm})$ compared with those for compound (1), (Finar, 1977). On the other hand, the structure of compound (2a) as a representative example, was confirmed by ${ }^{1} \mathrm{H}-\mathrm{NMR}$ spectra which shows significant peaks at $\delta(\mathrm{ppm}): 3.4\left(\mathrm{~s}, 2 \mathrm{H}, \mathrm{CH}_{2}\right), 7.5-7.9(\mathrm{~m}, \mathrm{H}$-aromatic) and 10.5-10.6 (d,2H,NH).

Reaction of compounds (2a-e) with ammonium acetate yielded the corresponding 2phenyl-1-(2-(5-aryl-1,2,4-triazole-3-yl)phenyl)ethanone derivatives (3a-e). Mechanistically, it is reasonable to assume that the ammonium acetate was decomposed under reflux conditions to releases ammonia and acetic acid (Konda et al.,2010; Bangar et al., 2008; Adib et al.,2006; Rao and Senthilkumar, 2004). Dehydrative condensation of ammonia and $\mathrm{C}=\mathrm{O}$ (amido) of compounds (2a-e) provides the intermediate (I). Subsequently, this intermediate undergoes intramolecule cyclization involving the other $\mathrm{C}=\mathrm{O}$ (amido) group to give compounds (3a-e) as shown in scheme (2) (Youssef, 2006). 
<smiles>O=C(NNC(=O)c1ccccc1C(=O)Cc1ccccc1)c1ccccc1</smiles><smiles>[X]c1cccc(C(=O)NN2C(=O)c3ccc(C(C)=O)cc3C(=O)C2c2ccccc2)c1</smiles><smiles></smiles>

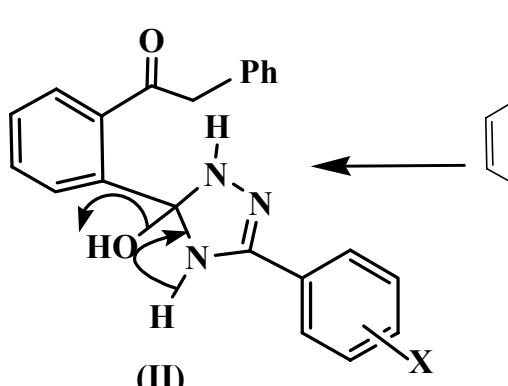

(II)<smiles>[X]c1ccc(C(=O)NN2C(=O)c3ccccc3C(=O)C2c2ccccc2)cc1</smiles>

$\left[\mathrm{X}=\mathrm{H} ; \mathrm{p}-\mathrm{Cl} ; \mathbf{2 , 4 - d i ~ C l} ;{\mathrm{p}-\mathrm{NO}_{2} ; 3,5-\mathrm{di} \mathrm{NO}}_{2}\right]$

\section{Scheme (2)}

The $\mathrm{NH}, \mathrm{C}=\mathrm{O}$ (ketone), $\mathrm{C}=\mathrm{C}$ (aromatic), $\mathrm{C}=\mathrm{N}$ (cyclic) and $\mathrm{N}-\mathrm{N}$ bonds stretching in IR spectra of the latter compounds appeared at $\left(3140-3244 \mathrm{~cm}^{-1}\right),\left(1658-1682 \mathrm{~cm}^{-1}\right),(1603-1611$; $\left.1475-1493 \mathrm{~cm}^{-1}\right),\left(1554-1631 \mathrm{~cm}^{-1}\right)$ and $\left(1072-1092 \mathrm{~cm}^{-1}\right)$ respectively, Table (2). Furthermore, in UV spectra these compounds showed a maximum absorption at $\lambda_{\max }(256-276 \mathrm{~nm})$, this reasing in absorption is attributed to the formation of 1,2,4-triazole ring (Lopyrev et al., 1977). The ${ }^{1} \mathrm{H}-\mathrm{NMR}$ measurement of compound $(3 \mathrm{~b})$ showed the following characteristic peaks at $\delta$ (ppm): $2.9\left(\mathrm{~s}, 2 \mathrm{H}, \mathrm{CH}_{2}\right), 7.2-7.9(\mathrm{~m}, \mathrm{H}$-aromatic) and $13.2(\mathrm{~s}, 1 \mathrm{H}, \mathrm{NH})$.

The purity of the synthesized compounds were checked by thin layer chromatography measurements, and this technique was also used to established the formation of compounds (3a-e) by comparing their $\mathrm{R}_{\mathrm{f}}$ values with those of compounds (2a-e) as listed in Tables (1 and 2) respectively.

Condensation of compounds (1) with substituted benzaldehyde was found to proceed concurrently to equation (3) (Kotb et al., 2009; Hsu et al., 2005; Cid et al., 2000) to give the corresponding N'-arylidene-2-( $\alpha$-phenylacetyl)benzohydrazide derivatives (4a-f). 


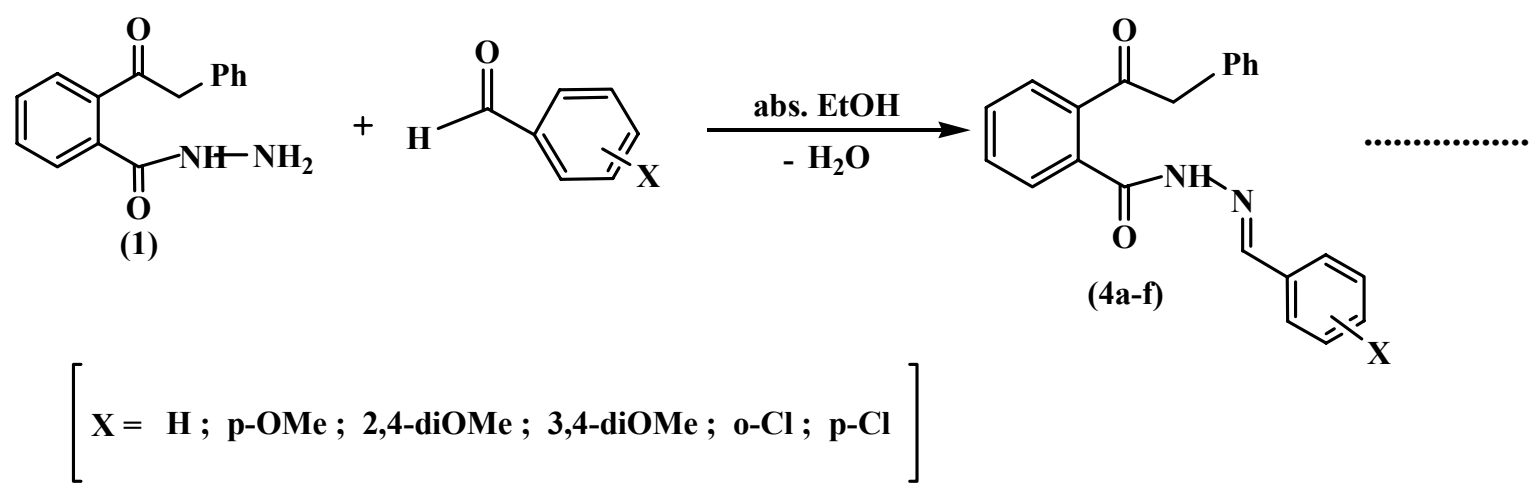

The structure of these compounds was confirmed from their spectral data, Table (3). Thus, the IR spectra of these compounds showed the following spectral bands: NH functional group at $\left(3161-3231 \mathrm{~cm}^{-1}\right),\left(1704-1728 \mathrm{~cm}^{-1}\right)$ and $\left(1655-1661 \mathrm{~cm}^{-1}\right)$ related to the $\mathrm{C}=\mathrm{O}$ groups (ketone and amide) respectively (Çakır and Biçer, 2010) and (1600-1608; 1491-1508 $\mathrm{cm}^{-1}$ ) related to $\mathrm{C}=\mathrm{C}$ (aromatic). In contrast, the appearance of the $\mathrm{C}=\mathrm{N}$ bond stretching at (1560$\left.1597 \mathrm{~cm}^{-1}\right)$ and $\mathrm{N}-\mathrm{N}=\mathrm{C}$ bond stretching at $\left(1542-1579 \mathrm{~cm}^{-1}\right)$ (Valentina et al., 2009; Solak and Rollas, 2006) gave an evidence for the formation of compounds (4a-f). Whereas, in UV spectra they gave assigned absorption bands at $\lambda_{\max }(284-352 \mathrm{~nm})$ due to the imine $\pi \rightarrow \pi^{*}$ transition (Hadi et al., 2009). The structure of compound (4e) was further identified by ${ }^{1} \mathrm{H}-\mathrm{NMR}$ spectrum, it showed a significant absorption peaks at $\delta(\mathrm{ppm}): 3.4\left(\mathrm{~s}, 2 \mathrm{H}, \mathrm{CH}_{2}\right), 4.3$ $(\mathrm{s}, 1 \mathrm{H}, \mathrm{CH}=\mathrm{N}), 7.1-8.9(\mathrm{~m}, \mathrm{H}$-aromatic $)$ and $12.7(\mathrm{~s}, 1 \mathrm{H}, \mathrm{NH})$.

Compounds (4a-f) can be considered as useful intermediate leading to formation several Heterocyclic compounds. Thus, the ring closure reaction of compounds (4a-f) in presence of excess acetic anhydride under reflux condition for (4hrs.) gave the corresponding 2-(2-phenyl acetyl)phenyl-4-acetyl-4,5-dihydro-5-aryl-1,3,4-oxadiazoles (5a-f) as shown in the following scheme (3) (Fuloria et al., 2009; Szilágyi et al., 2004; Boyd and Dando, 1971 ).

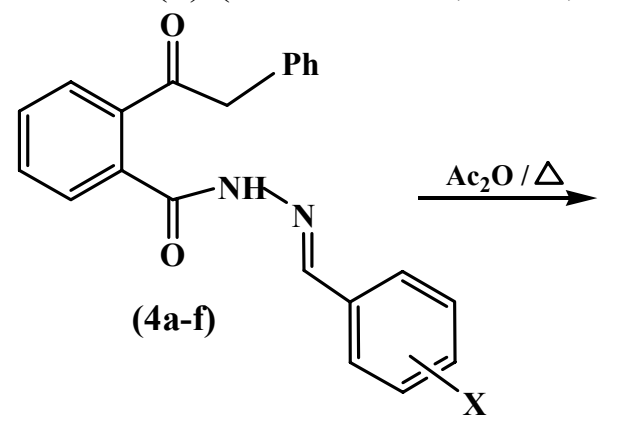

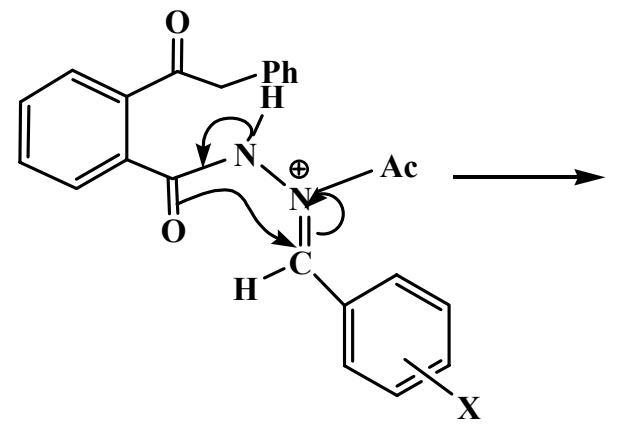<smiles>[X]c1ccc(C2OC(c3ccccc3C(=O)Cc3ccccc3)=NN2C#N)cc1</smiles>

$[\mathrm{X}=\mathrm{H} ;$ p-OMe $;$ 2,4-diOMe ; 3,4-diOMe ; o-Cl $;$ p-Cl $]$

Scheme (3) 
In each case, IR and UV spectra of the isolated products completely agree with the suggested structure, Table 4. The IR spectra show a characteristic bands at $\left(1163-1190 \mathrm{~cm}^{-1}\right)$ $\left(1600-1616 ; 1491-1495 \mathrm{~cm}^{-1}\right),\left(1558-1597 \mathrm{~cm}^{-1}\right),\left(1650-1674 \mathrm{~cm}^{-1}\right)$ and $\left(1709-1759 \mathrm{~cm}^{-1}\right)$ related to $\mathrm{C}-\mathrm{O}-\mathrm{C}$ (cyclic), $\mathrm{C}=\mathrm{C}$ (aromatic), $\mathrm{C}=\mathrm{N}, \mathrm{C}=\mathrm{O}$ (amide) (Islam and Mohsin, 2007) and $\mathrm{C}=\mathrm{O}$ (ketone) bonds stretching respectively. The UV spectra, on the other hand showed blue shift with maximum absorption at $\lambda_{\max }(232-250 \mathrm{~nm})$ which assigned to the formation of 1,3,4oxadiazoline ring (Kudelko and Zieliński, 2009), this provided additional evidence for the formation of compounds (5a-f). On the other hand, the ${ }^{1} \mathrm{H}-\mathrm{NMR}$ measurement of compound (5f) as a representative example showed the following characteristic peaks at $\delta(\mathrm{ppm}): 2.4\left(\mathrm{~s}, 3 \mathrm{H}, \mathrm{CH}_{3}\right), 3.4\left(\mathrm{~s}, 2 \mathrm{H}, \mathrm{CH}_{2}\right), 6.7(\mathrm{~s}, 1 \mathrm{H}, \mathrm{CH}-$ oxadiazoline $)$ and 7.2-8.5 (m,Haromatic).

It is also worth noting that compounds 2-( $\alpha$-phenylacetyl)- $\mathrm{N}-(3,6$-diphenyl-5-aryl-5,6dihydro-1,2,4-triazine-4yl)benzamide (6a-f) were prepared through direct Diels-Alder reaction between dibenzylidene hydrazine (III) as diene (was prepared by condensation of hydrazine hydrate $(80 \%)$ with benzaldehyde in the presence of aqueous acetic acid $(50 \%)$ to give yellowish green crystalline products in a good yield (Sharma et al., 2008) as shown in scheme (4), equation 4) and compounds (4a-f) as dienophile. The reaction was found to proceed smoothly under microwave irradiation within (6 min.) at (360 watt), (scheme 4) (Carey,1996).

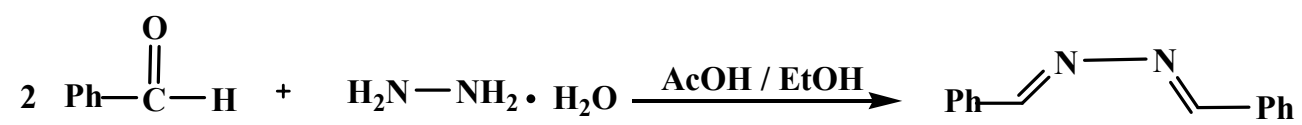<smiles>[X]c1ccccc1/C=N/NC(=O)c1ccccc1C(=O)Cc1ccccc1</smiles>

(4a-f)<smiles>[X]c1ccccc1C1C(c2ccccc2)N=NC(CC)N1NC(=O)c1ccccc1C(=O)Cc1ccccc1</smiles>

$[\mathrm{X}=\mathrm{H} ; \mathrm{p}$-OMe $;$ 2,4-diOMe ; 3,4-diOMe ; o-Cl $; \mathrm{p}-\mathrm{Cl}]$

Scheme (4) 
The products were elucidated from their spectral analysis, Table (5). The IR spectra they show absorption bands at $\left(3289-3356 \mathrm{~cm}^{-1}\right)$ related to $\mathrm{NH}$ functional group, $\left(1713-1750 \mathrm{~cm}^{-1}\right)$ assigned to $\mathrm{C}=\mathrm{O}$ (ketone) functional group, $\left(1655-1657 \mathrm{~cm}^{-1}\right)$ assigned to $\mathrm{C}=\mathrm{O}$ (amide) functional group, $\left(1618-1625 ; 1491-1493 \mathrm{~cm}^{-1}\right)$ related to $\mathrm{C}=\mathrm{C}$ (aromatic), $\left(1556-1593 \mathrm{~cm}^{-1}\right.$ ) assigned to $\mathrm{N}=\mathrm{N}$ functional group, $\left(1346-1378 \mathrm{~cm}^{-1}\right)$ assigned to $\mathrm{C}-\mathrm{N}$ functional group and at (1074-1084 $\mathrm{cm}^{-1}$ ) assigned to $\mathrm{N}-\mathrm{N}$ functional group. The absence of $\mathrm{C}=\mathrm{N}$ absorption band and the presence of $\mathrm{N}=\mathrm{N}$ absorption bands indicate clearly the formation of compounds (6a-f). Also, these compounds have UV absorption between (298-304 nm) comparing with those for compounds (4a-f). Furthere identification of compound (6e) has came from $\mathrm{H}^{1}-\mathrm{NMR}$ measurement, which showed significant peake at $\delta(\mathrm{ppm}): 2.4(\mathrm{~s}, 1 \mathrm{H}, \mathrm{CH}), 2.6(\mathrm{~s}, 1 \mathrm{H}, \mathrm{CH}), 3.3$ $\left(\mathrm{s}, 2 \mathrm{H}, \mathrm{CH}_{2}\right), 4.3(\mathrm{~s}, 1 \mathrm{H}, \mathrm{CH})$ and $7.1-8.9(\mathrm{~m}, \mathrm{H}$-aromatic) and $12.7(\mathrm{~s}, 1 \mathrm{H}, \mathrm{NH})$.

Finally, ethyl acetate: dichlor methane, was used as suitable solvent system in thin layer chromatography measurements to give an indication about the formation of compounds (5a-f) and (6a-f) and also comparing their $R_{f}$ values with those of the starting materials represented by compounds (4a-f) as shown in Tables (5,4 and 3$)$ respectively. 
The Use of 3-Bezylidene Phthalide........

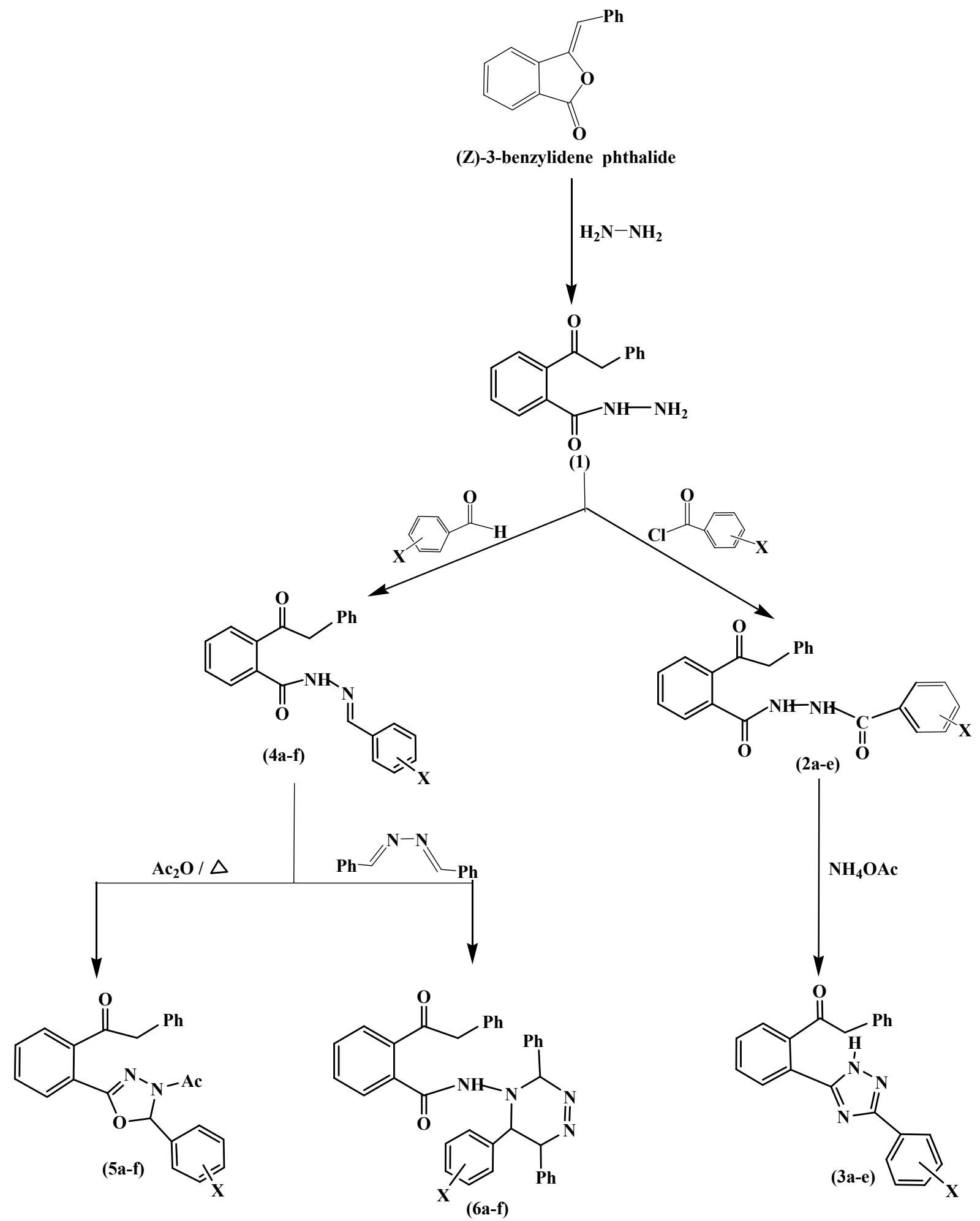

Scheme (5) 


\section{REFERENCES}

Abd El-Fattah, O.; Abbas, E. M. H.; Ahmed, N. (2010). Synthesis and evaluation of some tetrahydropyrimidine derivatives as antimicrobial, Aust. J. Basic and Appl. Sci., 4(1), 27-36.

Adib, M. ; Tahermansouri, H.; Koloogani, S. A.; Mohammadi, B.; Bijanzadeh, H. R. (2006). Kro"hnke pyridines: an efficient solvent-free synthesis of 2,4,6-triarylpyridines, Tetrahedron Letters ,47, 5957-5960.

Bandgar, B.P.; More, P.E.; Kamble, V. T.; Totre, J.V. (2008). Synthesis of polyhydroquinoline derivatives under aqueous media, ARKIVOC, XV, 1-8.

Boyd, G.V.; Dando, S.R. (1971). The dimerisation of 5-methylene- $\Delta^{2}-1,3,4$-oxadiazolines, $J$. Chem. Soc.(C), 2314-2318.

Çakır, S.; Biçer, E. (2010). Synthesis, spectroscopic and electrochemical characteristics of a novel schiff-base from saccharin and tryptophan, J. Iran. Chem. Soc., 7(2), 394-404.

Carey, F.A. (1996). "Organic Chemistry ". 3rd edn., McGraw-Hill Companies, Inc., 398 p.

Chérouvrier, J.R.; Bazureau, J.P. (2001). A practical and stereoselective rout to 5-ylidene3,5-dihydroimidazole-4-one derivatives using solvent-free conditions under focused Microwave irradiations, ECSOC-5, 1-7.

Chiriac, C.I.; Nechifor, M.; Tanasa, F. (2007). Formamide, a novel challenging reagent for the direct synthesis of non-substituted cyclic, Revue Roumaine de Chimie, 52(8-9), 883886.

Cid, H.M.B.; Tra“nkle, C. ; Baumann, K.; Pick, R.; Mies-Klomfass, E. (2000). Structureactivity relationships in a series of bisquaternary bisphthalimidine derivatives modulating the muscarinic M2-receptor allosterically, J. Med. Chem., 43, 2155-2164.

Conner, D.E. (1982). Benzalphthalides and broad spectrum sun screen, U.S. Patent, 4,333,920.

Dalloul, H. M. (2010). Heterocyclic synthesis using nitrilimines: part 14.synthesis of new pyrazole derivatives, Turk J. Chem., 34, 529-535.

Dalloul, H.M.; Al-Shorafa, A.Z. (2009). On reactions of triazinones: Synthesis of new 5arylidene-4,5-dihydro-1,2,4-triazine-6-ones, Org. Commun., 2(1), 20-27.

Deka, N.; Mariotte, A.; Boumendjel, A. (2001). Microwave mediated solvent-free acetylation of deactivated and hindered phenols, Green Chemistry, 3, 263-264.

Del Olmo, E.; Barboza, B.; Ybarra, M. I.; Lo'pez-Pe'rez, J. L.; Carro'n, R.; Sevilla, M.A.; Bosellid, C.; Felicia, A.S. (2006). Vasorelaxant activity of phthalazinones and related compounds, Bioorganic and Medicinal Chemistry Letters, 16, 2786-2790.

Demirbas, N.; Demirbas, A.; Karaoglu, S.A.; Celik, E. (2005). Synthesis and antimicrobial activities of some $[1,2,4]$ triazolo[3,4-b][1,3,4]thiadiazoles and $[1,2,4]$ triazolo[3,4-b] $[1,3,4]$ thiadiazines, ARKIVOC, I, 75-91.

Ferwanah, A.S.; Awadallah, A.M. (2005). Reaction of nitrilimines and nitrile oxides with hydrazines, hydrazones and oximes, Molecules , 10, 492-507.

Finar, I.L. (1977). "Organic Chemistry". Longman, Vol. 2, pp.17-18.

Fuloria, N.K.; Singh, V.; Shaharyar, M.; Ali, M. (2009). Synthesis and antimicrobial evaluation of some new oxadiazoles derived from phenylpropionohydrazides, Molecules, 14, 1898-1903. 
Ganji, S.H.; Karigar, C.S.; Pujar, B.G. (1993). Metabolism of benzalphthalide by Pseudomonas sp, World J. Microbiol. and Biotechnol., 9, 597-598.

Hadi, J.S.; Alsalami, B.K.; Essa, A.H. (2009). Synthesis, spectroscopic characterization and theoretical study of schiff bases derived from phenylsulfonylamide, J. Sci. Res., 1(3), 563-568.

Hrnčiar, P.; Ertl, P.; Hrnčiar, P.; Toma, Š. (1994). Complexation of phthalides and substituted 3-benzylidene phthalides with $\mathrm{Cr}(\mathrm{CO})_{6}$, J. Organometallic Chem., 464 (1), 65-69.

Humber, L.G. (1974). 5-Cycloalkylidene dibenzocycloheptene derivatives, U.S. Patent, 3, 832,405 .

Hus, W.; Tao, T.; Liu, K. (2005). Condensed naphtho[1,8-de][1,3]thiazine 2. an orientating structure modification of naphtho[1,8-de][1,2,4]-triazolo $[3,4-\mathrm{b}][1,3]$ thiazine ring system, Chin. Pharm. J., 57(1), 43-48.

Ibrahim, T.M. (1991). Synthesis of biological active 3- benzylidenephthalide derivatives, Arch. Pham. Res., 14(4), 342-345.

Islam, Md. R.; Mohsin, M. (2007). Synthesis of isatin, 5-chloroisatin and their $\Delta^{2}-1,3,4-$ oxadiazoline derivatives for comparative cytotoxicity study on brine shrimp, Bangladesh J. Pharmacol, 2, 7-12.

Kamble, R.R.; Sudha, B.S. (2006). Synthesis, spectral characterization and antihaemostatic activity of 1,2,4-triazoles incorporating 1,2,4-triazine ring, J. Chem. Sci., 118(2), 191195.

Kanazawa, C.; Terada, M. (2007). Organic-base-catalyzed synthesis of phthalides via highly regioselective intramolecular cyclization reaction, Tetrahedron Lett., 48(6), 933-935.

Katritzky, A.R. ; Rees C.W., (1984). "Comprhensive Heterocyclic Chemistry ". Progman, New York, (a) Vol. 4, pp.353; (b) Vol. 5, pp.784-785; (c)Vol. 6, pp.445-446.

Khanage, S.G.; Mohite, P.B.; Pandhare, R.B.; Deshmukh, V.K.; Raju, S.A. (2010). A rational approach for synthesis and characterization of 5-[(5-phenyl-1H-tetrazol-1yl) methyl]-3(substituted aryl)-4H-1,2,4-triazoles, Drug Invention Today, 2(4), 240243.

Khare, P.K.; Srivastava, A.K.; Singh, H. (2005). Synthesis and fungicidal activity of some 6-Aryl-2-(- $\beta$-D-glucopyranosyl)-3-oxo-2,3-dihydro-1,3,4-oxadiazolo[3,2-b]-1,2,4,6thiatriazine-1,1-dioxides, Indian Journal of Chemistry, 44B, 163-166.

Konda, S.G.; Khedkar, V.T.; Dawane, B.S. (2010). Synthesis of some new 2-amino-3cyano-4-aryl-6-(1-napthyl amino)-pyridines as antibacterial agents, J. Chem. Pharm. Res., 2(1), 187-191.

Kotb, E.R.; El-Hashash, M.A.; Salama, M.A.; Kalf, H.S.; Abdel Wahed, N.A.M. (2009). Synthesis and reactions of some novel nicotinonitrile derivatives for anticancer and antimicrobial evaluation, Acta Chim. Slov., 56, 908-919.

Kudelko, A.; Zieliński, W. (2009). An effective conversion of $N$ '-ethoxymethylene-2-( $N$-Bocamino) propionohydrazides into 2-(1-aminoethyl)-1,3,4-oxadiazoles, ARKIVOC, XIV, $1-8$.

Kundu, N.G.; Pal, M.; Nandi, B. (1998). Palladium-catalysed heteroannulation with terminal alkynes:synthesis of phthalides, J. Chem. Soc., Perkin Trans., 1, 561-568. 
Kurume, A.; Kamata, Y.; Yamashita, M.; Wang, Q.; Matsuda, H.; Yoshikawa, M.; Kawasaki, I.; Ohta, S. (2008). Synthesis of 3-substituted isocoumarins and their inhibitory effects on degranulation of RBL-2H3 cells induced by antigen, Chem. Pharm. Bull., 56(9), 1264- 1269.

Lenardao, E.J.; Silva, M.S.; Mendes, S.R.; de Azambuja, F.; Jacob, R.G.; dos Santos, P.C.S. ; Perin, G. (2007). Synthesis of $\beta$-phenylchalcogeno- $\alpha, \beta$-unsaturated ester, ketone and nitriles using microwave and solvent-free conditions, J. Braz. Chem. Soc., 18 (5),1-12.

Litvan, F.; Stoll, W. (1958). Substituted 2-phenyl indan-1,3-dione, U.S. Patent, $2,820,738$.

Lopyrev, V.A.; Chipanina, N.N.; Rozinova, L.G.; Sarapulova, G.I.; Sultangareev, R.G.; Voronkov, M.G. (1977). Synthesis and absorption spectra of 3,5-diaryl-1,2,4-triazoles, Chemistry of Heterocyclic Compounds, 13 (2), 1346-1349.

Mulwad, V. V.; Chashar, A.C. (2006). Synthesis and antibacterial activity of new oxadiazolo [1,3,5]-triazine,1,2,4-triazolo and thiadiazolo 1,3,4-oxadiazole derivatives, Indian $J$. Chem., 45B, 1710-1715.

Nasr, A. Z. (2005). First synthesis of double headed 1,2,4-triazino[5,6-b]indole acyclo Cnucleosides, J. Chin. Chem. Soc., 52(3), 519-524.

Parikh, V.M. (1974). "Absorption Spectroscopy of Organic Molecules". Addision Wesely Publishing Comp., Inc., 30p.

Patel, C.K.; Rami, C.S.; Panigrahi, B.; Patel, C.N. (2010). Synthesis and biological evaluation of (4-substituted benzylidene)-3-methyl-1-(substituted phenyl sulfonyl and substituted benzoyl)-1Hpyrazol-5(4H)-one as anti-inflammatory agent, J. Chem. Pharm. Res., 2(1), 73-78.

Phucho, T.; Nongpiur, A.; Tumtin, S.; Nongrum, R.; Myrboh, B.; Nonghlaw, R.L. (2008). Novel one pot synthesis of substituted 1,2,4-triazines, ARKIVOC, XV, 79-87.

Pisarenko, L.M.; Gagarina, A.B.; Sveshnikov, N.N. (1992). E and Z Stereoisomers of compounds of the phthalide series, Russian Chem. Bull., 41(21), 231-235.

Rao, H.S.P.; Senthilkumar, S.P. (2004). Microwave-mediated reductive aminationcyclization of 4-aryl-4-oxobutanoates: Facile synthesis of 3-methylidene-5-phenyl-2,3dihydropyrrolidones, J. Chem. Sci., 116( 3), 163-168.

Rios, M.Y.; Delgado, G. (1999). Lewis acid catalyzed transformations Z-ligustilide, J. Mexican Chem. Soc., 43(3,4), 127-32.

Rosenthal, A.; Yalpani, M. (1965). Reaction of aralkyl ketone phenylhydrazones with carbon monoxide; thermal indolization of aralkyl ketone phenylhydrazones, Canadian J. Chem., 43, 3449-3451.

Sasaki, T.; Ohno, M.; Ito, E. (1984). Synthesis of fused s-triazoles from 2-methanesulfonyl -5-phenyl-1,3,4-oxadiazole and binnucleophilic reagents by means of intramolecular ring transformation, Chem. Pharm. Bull., 32(12), 5040-5043.

Scholl, T.; Serini, V.; Rathmann, D.; Savage, R.; Kircher, K. (1989). Use of 3-benzalphthalide as uv stabilizers for thermoplastic, aromatic polyesters, polycarbonates and polyester carbonates, U.S. Patent, 4,797,435. 
Shaban, M.A.E.; Nasr, A.Z.; El-Badry, S.M. (1991). Synthesis and biological activities of some 1,3,4-oxadiazoles and bis (1,3,4-oxadiazoles), J. Islamic Academy Sciences, 4(3), 184191.

Shafiee, A.; Nami, E.; Mansobi, P.; Foroumadi, A.; Shekari, M. (1995). Synthesis of substituted oxazolo-1,3,4-thiadiazoles,1,3,4-oxadiazoles, and 1,2,4-triazoles, $J$. Heterocyclic Chem., 32, 1235-1239.

Sharma, P.; Kumar, A.; Sahu, V.; Singh J. (2008). Diels-Alder reaction strategy to synthesize 1,2,3,6-tetrahydro-1,2,4,5-tetrazines and exploration of their antiinflammatory potential, ARKIVOC, XII, 218-225.

Shibata, T.; Gaesser, G. (1991). Sensitizer for heat paper coatings, U.S. Patent, 5,066,633.

Singh, R. J. (2009). Syntheses, characterization and antimicrobial screening of some novel 3,5-diaryl-4H-1, 2, 4-triazole derivatives, Der Pharma Chemica, 1(1), 141-145.

Sobkowski, M. (2008). Diverse chemoselectivity during acylation of nucleosides, Collection Symposium Series, 10, 277-281.

Solak, N.; Rollas, S. (2006). Synthesis and antituberculosis activity of 2-(aryl/alkylamino)5-(4-aminophenyl)-1,3,4-thiadiazoles and their Schiff bases, ARKIVOC , XII, 173181.

Swamy, V.R.; Periathai, R.S.; Rajagopal, K.; Krishnakumar, R.V.; Srinivasan, N. (2010). 8- (2-Chlorophenyl)-1-(4-chlorophenyl)-4-[(E)-(2-chlorophenyl)methylidene]-6methyl- $\quad 4,5,6,7,7 \mathrm{a}, 8$-hexahydro-1,2,4-oxadiazolo[5,4-d]pyrido[3,4-c][1,5]-benzo thiazepine, Acta Cryst., E66, 01119.

Szilágyi, L.; Illyés, T.Z. ; Györgydeák, Z.; Szabó, G.; Karácsony, A. (2004). Syntheses of partially hydrogenated $[1,2,4]$ triazolo[4,5-a]pyrimidine-4-ones through cyclisation of 2-arylidenehydrazino-6-methyl-4-pyrimidones, ARKIVOC, VII, 243-252.

Taha, M.A.M.; El-Badry, S. M. ( 2006). Synthesis of 1,3,4-oxadiazole acyclo C-nucleosides bearing 5-methylthio $\{7$-substituted-1,2,4-triazolo[1,5-d]tetrazol-6-yl\}moieties, $J$. Chin. Chem. Soc., 53, 1181-1188.

Trotsko, N.; Dobosz, M.; Jtowicz, E. J. (2007). Cyclization of thiosimecarbazide derivatives of 5-arylidene -2,4-dioxothiazolidine-3-acetic acids to 1,3,4-thiadiazoles and their pharmacological properties, Acta Poloniae Pharmaceutica Drug Research, 64 (3), 227- 231.

Valentina, P.; Ilango, K.; Deepthi, M.; Harusha, P.; Pavani, G.; Sindhura, K. L.; Keerthanan, CH.G. (2009). Antioxidant activity of some substituted 1, 2, 4 - triazo-5-thione schiff base, J. Pharm. Sci. and Res., 1(2), 74-77.

Viña, D. ; del Olmo, E.; Lopez-Pérez, J. L.; Feliciano, A.S. (2008). Pyrazolo[3,4,5- de] phthal- azine. Syntheses of a practically unknown heterocyclic system, Tetrahedron, 65(8), 1574-1580.

Xiuying, L.; Zhiguang, M.; Shigang, S.; Jinhuan, S.; Baoan, D. (2003). Synthesis of N-benzylphthalimide by polyethylene glycol-400 as phase transfer catalyst under microwave irradiation, Aug.15(8), 66. 
Yan, C.; Cai, X.; Wang, Q.; Wang, T.; Zheng, M. (2007). Microwave-assisted fourcomponent, one-pot condensation reaction: an efficient synthesis of annulated pyridines, Org. Bio. Chem., 5, 945-951.

Yıldırım, I.; Kandemirli F.; Demir, E. (2005). Experimental and theoretical studies on the Functionalization reactions of 4-benzoyl-1,5-diphenyl-1H-pyrazole-3-carboxylic acid and acid chloride with 2,3-diaminopyridine, Molecules, 10,559-571.

Youssef, A.S. A. (2006). Reactions of 3-substituted 5-arylmethylene -1, 3-thiazolidin-2, 4diones with azide and cyanide ions, World J. Chem., 1 (1), 10-19. 